\title{
Selection Satisfaction and Attributes of Higher Education Institutions: Mediation of Information Satisfaction
}

\section{Irfandi Buamonabot (D), Muhammad Asril Arilaha ${ }^{(D)}$, and Johan Fahri *}

Department of Management, Faculty of Economics and Business, Universitas Khairun, 97719,

Ternate, North Maluku Province, Indonesia

* Corresponding Author: johan.fahri@unkhair.ac.id

\begin{tabular}{l}
\hline ARTICLE INFO \\
\hline $\begin{array}{l}\text { Publication Info: } \\
\text { Research Article }\end{array}$ \\
How to cite: \\
Buamonabit, I., Arilaha, M. A, E \\
Fahri, J. (2021). Selection \\
Satisfaction and Attributes of \\
Higher Education Institutions: \\
Mediation of Information \\
Satisfaction. Society, 9(1), 228- \\
240.
\end{tabular}

DOI: $10.33019 /$ society.v9i1.292

Copyright $($ C) 2021. Owned by Author(s), published by Society

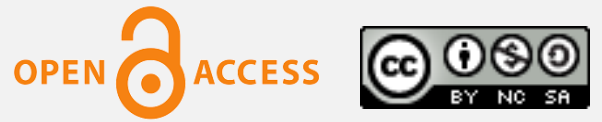

This is an open-access article.

\section{License: Attribution- \\ NonCommercial-ShareAlike (CC BY-NC-SA)}

Received: January 13, 2021; Accepted: June 30, 2021; Published: June 30, 2021;

\begin{abstract}
This study aimed to examine the satisfaction of information availability in mediating the relationship between attributes of and satisfaction in choosing higher education institutions for Universitas Khairun and IAIN Ternate. A total of 252 students from both institutions were involved in this survey, with an effective rate of return of $70 \%$. A hierarchical regression analysis was run by using IBM SPSS version 24. The results showed that for Universitas Khairun, information satisfaction fully mediates the relationship between attributes and satisfaction in choosing a university. In contrast, for IAIN Ternate, information satisfaction is only an independent variable. The implications and suggestions for further research are also discussed in this study.
\end{abstract}

Keywords: Attributes; Higher Education; Information Satisfaction; Selection Satisfaction 


\section{Selection Satisfaction and Attributes of Higher Education Institutions: Mediation of Information Satisfaction}

\section{Introduction}

Universities are interested in improving quality as part of policies to strengthen competitiveness (Cha \& Seo, 2019). The level of competition that is increasingly competitive in terms of admission of prospective students has resulted in each university trying to provide detailed information services for decision-making based on this information. The Internet is considered one of the main sources of information for prospective students, highlighting the importance of websites for universities (Brown et al., 2009; Ismail, 2013a; Maslowsky, 2014). Prospective students will gather information about universities and spend a long time getting relevant information and choosing universities (Lubbe \& Petzer, 2016), so that satisfaction with information will impact the choice of the college. When prospective students do not receive information about the lecture system at a university, it will certainly be very risky, so that the process of searching for further information is still carried out to minimize this risk (Brown et al., 2009). Identifying and measuring satisfaction can explain the aspects of the attributes that will greatly impact the college choice process (Verghese \& Kamalanabhan, 2015).

The study results also support the explanation above that higher education attributes positively affect satisfaction in choosing higher education. Higher education attributes positively affect information satisfaction, and information satisfaction positively affects satisfaction in choosing higher education (Sudarwo et al., 2018; Buamonabot et al., 2019; Sudarwo et al., 2019). Research that examines information satisfaction as a mediation of the relationship between higher education attributes and satisfaction in choosing higher education was first conducted. The results show information satisfaction as a partial mediation for private universities in Malaysia. This study aims to test information satisfaction as mediation at two state universities in North Maluku. This objective is also a recommendation from the research results (Ismail et al., 2010).

\section{Literature Review}

\subsection{Selection Satisfaction}

Customer satisfaction is defined as a consumer's response to meeting customer expectations. For this reason, long-term relationships with consumers must be maintained because it will impact the company's success (Zhang et al., 2019). Consumer satisfaction is a popular research theme in various social and economic sectors (Ardani et al., 2019). Concerning higher education, ensuring that students remain loyal and satisfied is the most important thing for universities because satisfied students will recommend the college to others. The indicators of selection satisfaction are feeling comfortable with the choice, satisfied with the choice, accurate selection, wise choice, satisfied with preferences, and the right decision (Ismail et al., 2010).

\subsection{Attributes of Higher Education Institutions}

Product attributes are product elements that are considered important by consumers and the basis for making purchasing decisions (Tjiptono, 2015). Product attributes also develop a product that offers more benefits for the product or service (Kotler \& Amstrong, 2018). According to consumer desires, the company seeks to make product variables to hope that product attributes can provide benefits to all consumers to foster consumer interest (Ahmad, 2019). In the higher education context, an attribute is something that is part or characteristic of the college. The attribute indicators in the higher education context are soft skill development, appropriate exemption, affordable education costs, internship opportunities, reasonable living 


\section{Selection Satisfaction and Attributes of Higher Education Institutions: Mediation of Information Satisfaction}

costs while studying in the city, financial assistance, campus atmosphere and allocations to a wider choice (Ismail et al., 2010).

\subsection{Information Satisfaction}

Information is very important for management in making decisions. Information satisfaction is an agreement of individuals satisfied in choosing a particular university (Ismail, 2008). Information satisfaction is a measure of the success of an information system (Machmud, 2019). Prospective students are satisfied with the information because universities provide information services through websites so that without coming directly, students already have comprehensive knowledge related to the information needed (Verghese \& Kamalanabhan, 2015). Information satisfaction is very important in the early stages of choosing a university (Menon et al., 2006). Prospective students gathering information regarding a particular college will depend on searching and assessing, and choosing a college. Indicators of information satisfaction in this study are satisfaction with information from website, information from useful websites and better decision making based on the information obtained (Ismail et al., 2010).

\subsection{Hypothesis}

\subsubsection{Effect of Attributes of Higher Education Institutions on Selection Satisfaction}

Overall consumer satisfaction or dissatisfaction with a transaction depends on evaluating the price and quality of the product or service provided. Assessment of consumer satisfaction can involve more than one comparison norm (Jones \& Shandiz, 2015). This includes adequate services concerning what is provided and obtained by consumers. Ensuring that consumers remain loyal and satisfied with their services is important for educational institutions so that educational institutions that are successful in the long period could satisfy consumers and generate profits. Indeed, it can be said that satisfying prospective students are the main obligation of higher education institutions and almost all activities, programs and policies must be evaluated in terms of their contribution to these prospective students. Therefore, the satisfaction of prospective students who will choose is very important for higher education. So that those who are superior must start with a comprehensive understanding of what attributes are the needs of prospective students who will choose a university, because the prospective students who are satisfied after choosing the college from time to time will return and bring more friends (Ismail et al., 2010; Davignon, 2015; Buamonabot et al., 2019; Sudarwo et al., 2019; Buamonabot et al., 2020). So the hypothesis proposed in this study is as follows.

H1a. Attributes of Higher Education Institutions have a positive effect on the Selection Satisfaction of Universitas Khairun's students.

H1b. Attributes of Higher Education Institutions have a positive effect on the Selection Satisfaction of IAIN Ternate's students.

\subsubsection{Effect of Attributes of Higher Education Institutions on Information Satisfaction}

Customer service always experiences difficulties related to the consequences of choosing that cannot be anticipated (Iglesias \& Guillén, 2002). This is, of course, due to the distinctive nature of the service (Parasuraman \& Zeithaml, 1985). Customers usually associate services that have a high level of risk (Murray, 1991). Therefore, education takes a long time even when decisions are made (undergraduate education takes more than 3.5 years). The accuracy of information related to the attributes of higher education is needed by prospective students (Verghese \& Kamalanabhan, 2015; Halstead et al., 1994). The results show that college attributes

Copyright (C 2021. Owned by Author(s), published by Society. This is an open-access article under the CC-BY-NC-SA license. https://doi.org/10.33019/society.v9i1.292 


\section{Selection Satisfaction and Attributes of Higher Education Institutions: Mediation of Information Satisfaction}

positively affect information satisfaction (Ismail \& Leow, 2008; Ismail et al., 2010; Sudarwo et al., 2019; Buamonabot et al., 2019; Buamonabot et al., 2020). Therefore, the hypothesis proposed is as follows.

H2a. Attributes of higher education institutions have a positive effect on the information satisfaction of Universitas Khairun's students.

$\mathrm{H} 2 \mathrm{~b}$. Attributes of higher education institutions have a positive effect on student information satisfaction of IAIN Ternate's students.

\subsubsection{Effect of Information Satisfaction on Selection Satisfaction}

Competition between tertiary institutions is getting tighter, and sources of information seeking are constantly changing, causing the importance of understanding the sources of information used by prospective students in choosing a university. Excessive information and many choices cause problems that can hinder prospective students from choosing the higher education institution (Ismail, 2013a; Ismail, 2013b; Lubbe \& Petzer, 2016). Quality information determines the level of satisfaction felt after the decision is made (Ismail et al., 2012). The results show that information satisfaction positively affects selection satisfaction (Ismail et al., 2010; Sudarwo et al., 2018; Sudarwo et al., 2019; Buamonabot et al., 2020), so the hypothesis proposed is as follows.

H3a. Information satisfaction has a positive effect on the selection of information of Universitas Khairun's students.

$\mathrm{H} 3 \mathrm{~b}$. Information satisfaction has a positive effect on the selection of information of IAIN Ternate's students.

\subsubsection{Information Satisfaction mediates the relationship between Attributes of Higher Education Institutions and Selection Satisfaction}

The information gathered about the respective tertiary institutions will form the basis for the main evaluation of prospective students to choose a college to study. Generally, prospective students will seek and evaluate information in the process of deciding whether to choose a higher education institution (Ismail \& Leow, 2008; Ismail, 2008) defines satisfaction with information as individual agreement and satisfaction with information used in selecting services. An important problem of concern for universities is understanding and following up on the results of evaluations by students. Apart from satisfaction after choosing a college, it is also relevant to know that satisfaction with information can occur before making choices (Ismail, 2009). During the early stages of the decision-making process, prospective students will evaluate potential services through the information obtained. Prospective students' expectations concerning services will depend heavily on information obtained directly from the source, impacting college performance assessments (Ismail et al., 2010). Based on this explanation, the hypothesis proposed is as follows.

H4a. Information satisfaction mediates the relationship between attributes of higher education institutions and selection satisfaction of Universitas Khairun's students

$\mathrm{H} 4 \mathrm{~b}$. Information satisfaction mediates the relationship between attributes of higher education institutions and selection satisfaction of IAIN Ternate's students.

\section{Research Methodology}

The population in this study were active students at Universitas Khairun and Institut Agama Islam Negeri Ternate (IAIN Ternate). Determination of the sample in this study using purposive sampling with judgment sampling approach with the condition that students who

Copyright (C 2021. Owned by Author(s), published by Society. This is an open-access article under the CC-BY-NC-SA license. https://doi.org/10.33019/society.v9i1.292 


\section{Selection Satisfaction and Attributes of Higher Education Institutions: Mediation of Information Satisfaction}

choose Universitas Khairun and IAIN Ternate do registration online. The sample in this study were 252 odd semester students (III, V and VII) consisting of 135 students from Universitas Khairun and 117 from IAIN Ternate. According to Roscoe et al. (1975), a sample size of 30-500 is considered appropriate for quantitative research. This study used validity and reliability tests with a factor loading value of $\geq 0.5$ (Hair et al., 2010) and Cronbach's Alpha $\geq 0.6$ (Ghozali, 2018). Hypothesis testing in this study uses regression analysis developed by (Baron \& Kenny, 1986). The questionnaire in this study used previous research, such as the satisfaction variable choosing a college using a questionnaire developed by Oliver (1997), the college attribute variable using a questionnaire developed by Chapman (1981), Halstead et al. (1994), Poock \& Love, (2001), Cubillo et al., (2006), Ismail et al., (2010) and the information satisfaction questionnaire using a questionnaire developed by Oliver (1997) and Ismail et al. (2010). The questionnaire in this study used a Likert scale of 5 (strongly disagree to strongly agree).

\section{Results and Discussion}

The results of distributing questionnaires show that of the 360 questionnaires distributed, only $269(74.72 \%)$ questionnaires were returned and declared eligible for further testing as many as $252(70 \%)$ questionnaires. Hence, the response rate in this study was $71 \%$.

The respondents' characteristics in this study were gender, age, and semester (see Table 1 of the respondent profile). The characteristics of the respondents in this study indicate that the majority of respondents in this study were 69.6\% women (91 respondents or 38.4\% of Universitas Khairun students and 74 IAIN Ternate students or 31\%), 57.5\% were 19 years old (83 respondents or 35\% of Universitas Khairun's students and 53 students of IAIN Ternate or $22.4 \%$ ) and most of them were in the third semester, namely $62.4 \%$ (85 respondents or $35.9 \%$ of Universitas Khairun's students and 63 students of IAIN Ternate or $26.6 \%$ ).

Table 1. Respondents Profiles

\begin{tabular}{|c|c|c|c|}
\hline Respondent Characteristics & Institution & Frequency & Percent (\%) \\
\hline \multicolumn{4}{|l|}{ Gender } \\
\hline - Male & Universitas Khairun & 44 & 18.6 \\
\hline - $\quad$ Male & IAIN Ternate & 43 & 18.1 \\
\hline - Female & Universitas Khairun & 91 & 38.4 \\
\hline - Female & IAIN Ternate & 74 & 31 \\
\hline \multicolumn{4}{|l|}{ Age } \\
\hline - 19 y.o. & Universitas Khairun & 83 & 35 \\
\hline - 19 y.o. & IAIN Ternate & 53 & 22.4 \\
\hline - 20 y.o. & Universitas Khairun & 31 & 13.1 \\
\hline - 20 y.o. & IAIN Ternate & 53 & 22.4 \\
\hline - 21 y.o. & Universitas Khairun & 16 & 9 \\
\hline - 21 y.o. & IAIN Ternate & 11 & 4.6 \\
\hline \multicolumn{4}{|l|}{ Semester } \\
\hline - $\quad$ Semester III & Universitas Khairun & 85 & 35.9 \\
\hline - $\quad$ Semester III & IAIN Ternate & 63 & 26.6 \\
\hline - Semester V & Universitas Khairun & 31 & 13.1 \\
\hline - Semester V & IAIN Ternate & 36 & 15.2 \\
\hline - $\quad$ Semester VII & Universitas Khairun & 19 & 8 \\
\hline
\end{tabular}

Copyright (C) 2021. Owned by Author(s), published by Society. This is an open-access article under the CC-BY-NC-SA license. https:// doi.org/10.33019/ society.v9i1.292 
Selection Satisfaction and Attributes of Higher Education Institutions: Mediation of Information Satisfaction

\begin{tabular}{|c|c|c|c|}
\hline Respondent Characteristics & Institution & Frequency & Percent (\%) \\
\hline - Semester VII & IAIN Ternate & 18 & 7.6 \\
\hline
\end{tabular}

Source: Processed Data (2019)

The validity test results for Universitas Khairun students show that both the variable selection information, attributes of higher education institutions, and information satisfaction, no question items are discarded because they meet the factor loading $\geq 0.5$. The reliability test results also show that both the three variables have a Cronbach alpha value of $\geq 0.6$, so the three variables can be valid and reliable. The results of testing the validity and reliability of Universitas Khairun students are shown in Table 2.

Table 2. Validity and Reliability Test Results (Universitas Khairun Students)

\begin{tabular}{|c|c|c|c|}
\hline Factor and Scale & Factor 1 & Factor 2 & Factor 3 \\
\hline \multicolumn{4}{|c|}{ Selection Satisfaction $=$ Cronbach a 0.757} \\
\hline Selection Satisfaction1 & 0.770 & & \\
\hline Selection Satisfaction2 & 0.695 & & \\
\hline Selection Satisfaction3 & 0.509 & & \\
\hline Selection Satisfaction4 & 0.742 & & \\
\hline Selection Satisfaction5 & 0.817 & & \\
\hline \multicolumn{4}{|c|}{ Attributes of Higher Education Institutions = Cronbach a 0.871} \\
\hline AHEI1 & & 0.563 & \\
\hline AHEI2 & & 0.655 & \\
\hline AHEI3 & & 0.587 & \\
\hline AHEI4 & & 0.735 & \\
\hline AHEI5 & & 0.688 & \\
\hline \multicolumn{4}{|c|}{ Information Satisfaction $=$ Cronbach $=$ a 0.804} \\
\hline Information Satisfaction1 & & & 0.807 \\
\hline Information Satisfaction2 & & & 0.798 \\
\hline Information Satisfaction3 & & & 0.937 \\
\hline
\end{tabular}

Source: Processed Data (2019)

In contrast to testing results of the validity of Universitas Khairun students, the validity testing of IAIN Ternate students for variable selection information and Attributes of Higher Education Institutions (AHEI) each discarded one question item, namely Selection Satisfaction3 and Attributes of Higher Education Institutions1 (AHEI1). They were below the factor loading value of 0.5 . The validity test was carried out twice. The second validity test shows that both the question items on the variable selection information and attributes of higher education institutions have met the factor loading $\geq 0.5$.

Furthermore, the information satisfaction variable also shows the same factor loading value as the other two variables. For reliability testing, it also shows the same results as Universitas Khairun students, namely the Cronbach Alpha value $\geq 0.6$, so it can be said that the question items in this study are valid and reliable. The results of testing the validity and reliability of Universitas Khairun students are shown in Table 3. 


\section{Selection Satisfaction and Attributes of Higher Education Institutions: Mediation of Information Satisfaction}

Table 3. Validity and Reliability Test Results (IAIN Ternate Students)

\begin{tabular}{|c|c|c|c|}
\hline Factor and Scale & Factor 1 & Factor 2 & Factor 3 \\
\hline \multicolumn{4}{|c|}{ Selection Satisfaction $=$ Cronbach $\alpha 0.757$} \\
\hline Selection Satisfaction1 & 0.760 & & \\
\hline Selection Satisfaction2 & 0.674 & & \\
\hline Selection Satisfaction3 & 0.739 & & \\
\hline Selection Satisfaction4 & 0.822 & & \\
\hline Selection Satisfaction5 & 0.760 & & \\
\hline \multicolumn{4}{|c|}{ Attributes of Higher Education Institutions $=$ Cronbach a 0.871} \\
\hline AHEI1 & & 0.689 & \\
\hline AHEI2 & & 0.622 & \\
\hline AHEI3 & & 0.692 & \\
\hline AHEI4 & & 0.726 & \\
\hline AHEI5 & & 0.689 & \\
\hline \multicolumn{4}{|c|}{ Information Satisfaction $=$ Cronbach $=\alpha 0.804$} \\
\hline Information Satisfaction1 & & & 0.802 \\
\hline Information Satisfaction2 & & & 0.698 \\
\hline Information Satisfaction3 & & & 0.882 \\
\hline
\end{tabular}

Source: Processed Data (2019)

The results of the descriptive analysis of students of Universitas Khairun and IAIN Ternate consist of selection satisfaction, attributes of higher education institutions and information satisfaction. The results show that Universitas Khairun and IAIN Ternate students perceive selection satisfaction in high conditions and attributes of higher education institutions following what students want. In contrast to the two previous variables, Universitas Khairun students perceived information satisfaction well but were perceived as neutral by students of IAIN Ternate.

Table 4. Student Perceptions about Selection Satisfaction, Attributes of Higher Education Institutions, and Information Satisfaction (Universitas Khairun and IAIN Ternate students)

\begin{tabular}{lccccccc}
\multicolumn{1}{c}{ Variable } & Institution & $\begin{array}{c}\mathbf{( \% )} \\
\text { Strongly } \\
\text { Disagree }\end{array}$ & $\begin{array}{c}\mathbf{( \% )} \\
\text { Disagree }\end{array}$ & $\begin{array}{c}(\mathbf{\%}) \\
\text { Neutral }\end{array}$ & $\begin{array}{c}\mathbf{( \% )} \\
\text { Agree }\end{array}$ & $\begin{array}{c}\mathbf{( \% )} \\
\text { Strongly } \\
\text { Agree }\end{array}$ & Modus \\
\hline Selection Satisfaction & $\begin{array}{c}\text { Universitas } \\
\text { Khairun }\end{array}$ & - & 1.48 & 8.89 & 72.59 & 17.04 & Agree \\
\hline Selection Satisfaction & $\begin{array}{c}\text { IAIN } \\
\text { Ternate }\end{array}$ & - & 1.71 & 16.24 & 68.38 & 13.68 & Agree \\
\hline $\begin{array}{l}\text { Attributes of Higher } \\
\text { Education Institutions }\end{array}$ & $\begin{array}{c}\text { Universitas } \\
\text { Khairun }\end{array}$ & - & - & 7.41 & 70.37 & 22.22 & Agree \\
\hline $\begin{array}{l}\text { Attributes of Higher } \\
\text { Education Institutions }\end{array}$ & $\begin{array}{c}\text { IAIN } \\
\text { Ternate }\end{array}$ & - & $0.85 \%$ & 18.80 & 63.25 & 17.09 & Agree \\
\hline $\begin{array}{l}\text { Information } \\
\text { Satisfaction }\end{array}$ & Khairun & 0.74 & 0.74 & 6.67 & 62.22 & 29.63 & Agree \\
\hline
\end{tabular}

Copyright (C) 2021. Owned by Author(s), published by Society. This is an open-access article under the CC-BY-NC-SA license. https://doi.org/10.33019/society.v9i1.292 


\section{Selection Satisfaction and Attributes of Higher Education Institutions: Mediation of Information Satisfaction}

\begin{tabular}{lccccccc}
\hline \multicolumn{1}{c}{ Variable } & Institution & $\begin{array}{c}(\mathbf{\%}) \\
\text { Strongly } \\
\text { Disagree }\end{array}$ & $\begin{array}{c}\mathbf{( \% )} \\
\text { Disagree }\end{array}$ & $\begin{array}{c}\mathbf{( \% )} \\
\text { Neutral }\end{array}$ & $\begin{array}{c}\mathbf{( \% )} \\
\text { Agree }\end{array}$ & $\begin{array}{c}(\mathbf{\%}) \\
\text { Strongly } \\
\text { Agree }\end{array}$ & Modus \\
\hline $\begin{array}{l}\text { Information } \\
\text { Satisfaction }\end{array}$ & IAIN & 3.42 & 23.93 & 43.59 & 23.08 & 5.98 & Neutral \\
\hline
\end{tabular}

Source: Processed Data (2019)

Based on the results of hypothesis testing, it shows that hypotheses $1 \mathrm{a}$ and $1 \mathrm{~b}$, namely attributes of higher education institutions, have a positive effect on the satisfaction selection of students of Universitas Khairun and IAIN Ternate $(\beta=0.315, \mathrm{t}=3,716, \mathrm{P}<0.05)$ and $(\beta=0.325, \mathrm{t}$ $=3,592, \mathrm{P}<0.05)$, hypothesis $2 \mathrm{a}$ attributes of higher education institutions has a positive effect on the satisfaction information of Universitas Khairun students $(\beta=0.329, t=3.001, P<0.05)$ and hypothesis $2 b$ attributes of higher education institutions has no effect on IAIN Ternate student satisfaction information $(\beta=0.053, \mathrm{t}=0.314, \mathrm{P}>0.05)$. Finally, hypothesis $3 \mathrm{a}$ has a positive effect on information satisfaction on student satisfaction at Universitas Khairun $(\beta=$ 0.338, $\mathrm{t}=5.496, \mathrm{P}<0.05)$ and information satisfaction has a negative effect on student satisfaction at IAIN Ternate $(\beta=-0.105, \mathrm{t}=-2.031, \mathrm{P}<0.05)$. The results of testing hypotheses $1 \mathrm{a}$, $1 b, 2 a, 2 b, 3 a$, and $3 b$ are shown in Table 5 .

Table 5. Hypothesis Testing Results

\begin{tabular}{lccccccc}
\hline \multirow{2}{*}{ Variable } & Institution & \multicolumn{2}{c}{ Selection Satisfaction } & \multicolumn{3}{c}{$\begin{array}{c}\text { Information } \\
\text { Satisfaction }\end{array}$} \\
\cline { 2 - 7 } & $\mathbf{B}$ & $\mathbf{t}$ & $\mathbf{S i g}$ & $\boldsymbol{\beta}$ & $\mathbf{t}$ & Sig \\
\hline $\begin{array}{l}\text { Attributes of Higher } \\
\text { Education Institutions }\end{array}$ & $\begin{array}{c}\text { Universitas } \\
\text { Khairun }\end{array}$ & 0.315 & 3.716 & 0.000 & 0.329 & 3.001 & 0.003 \\
\hline $\begin{array}{l}\text { Attributes of Higher } \\
\text { Education Institutions }\end{array}$ & IAIN Ternate & 0.325 & 3.592 & 0.000 & 0.053 & 0.314 & 0.754 \\
\hline $\begin{array}{l}\text { Information } \\
\text { Satisfaction }\end{array}$ & $\begin{array}{c}\text { Universitas } \\
\text { Khairun }\end{array}$ & 0.338 & 5.496 & 0.000 & - & - & - \\
\hline $\begin{array}{l}\text { Information } \\
\text { Satisfaction }\end{array}$ & IAIN Ternate & -0.105 & -2.031 & 0.045 & - & - & - \\
\hline
\end{tabular}

Source: Processed Data (2019)

Finally, hypotheses $4 \mathrm{a}$ and $4 \mathrm{~b}$ show that information satisfaction mediates the relationship between attributes of higher education institutions and selection satisfaction of Universitas Khairun students. However, information satisfaction did not mediate the relationship between higher education institutions' attributes and selection satisfaction of IAIN Ternate students. This can be seen from the effect of direct information satisfaction, which is 0.315 , with the mediation value increasing to 0.426 , so that information satisfaction is the full mediation variable of Universitas Khairun students. For IAIN Ternate students, the effect of direct information satisfaction is 0.325 , with the value mediation has decreased $(-0.020)$. The information satisfaction variable has not become a mediating variable and only as an independent variable. The results of testing hypotheses $4 \mathrm{a}$ and $4 \mathrm{~b}$ are shown in Table 6 below.

Copyright (C) 2021. Owned by Author(s), published by Society. This is an open-access article under the CC-BY-NC-SA license. 
Selection Satisfaction and Attributes of Higher Education Institutions:
Mediation of Information Satisfaction

Table 6. Direct, Indirect and Total Effect For Information Satisfaction as Mediating Variable

\begin{tabular}{lcccc}
\hline \multicolumn{1}{c}{ Variable } & Institution & Direct & Indirect & Total Effect \\
\hline $\begin{array}{l}\text { Attributes of Higher Education } \\
\text { Institutions - Selection Satisfaction }\end{array}$ & Universitas Khairun & 0.315 & 0.111 & 0.426 \\
\hline $\begin{array}{l}\text { Attributes of Higher Education } \\
\text { Institutions - Selection Satisfaction }\end{array}$ & IAIN Ternate & 0.325 & -0.010 & -0.020 \\
\hline
\end{tabular}

Source: Processed Data (2019)

The results of hypothesis testing show that hypotheses $1 \mathrm{a}$ and $1 \mathrm{~b}$ are significant positives. This shows that the satisfaction obtained by students from the attributes offered by higher education institutions, namely Universitas Khairun and IAIN Ternate, is considered to be as expected. This result is also supported by the research results of Ismail et al. (2010), Davignon (2015), Buamonabot et al. (2019), Sudarwo et al. (2019) and Buamonabot et al. (2020) that student satisfaction in choosing a college is very much determined by the attributes attached to the university.

The results of testing hypotheses $2 \mathrm{a}$ and $2 \mathrm{~b}$ show a significant and insignificant positive. This shows that the attributes offered by Universitas Khairun have been listed in official fields, so this will make it easier for prospective students who want to get the information needed. This result is following the research of Ismail \& Leow (2008), Ismail et al. (2010), Sudarwo et al. (2019), Buamonabot et al. (2019), Buamonabot et al. (2020). This result is different from the IAIN Ternate, which is not significant. This is because the information related to attributes is not on the official website of IAIN Ternate, so that new student candidates must come directly to the college.

In contrast to the results of testing hypotheses $1 \mathrm{a}, 1 \mathrm{~b}, 2 \mathrm{a}$, and $2 \mathrm{~b}$, hypotheses $3 \mathrm{a}$ and $3 \mathrm{~b}$ in their testing show conflicting results, namely significant positive and negative. This shows that the information from the official website of Universitas Khairun received and used by prospective students is one of the main factors in choosing a university. The information provides satisfaction for the prospective student. These results are also following the research of Ismail et al. (2010), Sudarwo et al. (2018), Sudarwo et al. (2019), and Buamonabot et al. (2020). The information obtained by prospective students received information that was not in detail from the official website of IAIN Ternate. When prospective students continued to choose the college, the consequences of dissatisfaction were received.

Hypotheses $4 \mathrm{a}$ and $4 \mathrm{~b}$ provide surprising results that the information satisfaction variable mediates the full relationship between attributes of higher education institutions and selection satisfaction. This means that when the attributes offered are following what is desired. It will certainly impact the satisfaction of prospective students, especially if these attributes are also available at the official site of Universitas Khairun. A different result is precisely the students of IAIN Ternate, where the information satisfaction variable does not mediate the relationship between attributes of higher education institutions and selection satisfaction. This means that information satisfaction is not a mediating variable but an independent variable. The results of this study are also inconsistent with Ismail et al. (2010) research that the satisfaction information mediates partially.

\section{Conclusion}

Based on the research results above, it can be concluded that first, attributes of higher education institutions positively affect selection satisfaction for both students of Universitas

Copyright (C 2021. Owned by Author(s), published by Society. This is an open-access article under the CC-BY-NC-SA license. https://doi.org/10.33019/society.v9i1.292

236 


\section{Selection Satisfaction and Attributes of Higher Education Institutions: Mediation of Information Satisfaction}

Khairun and IAIN Ternate. Second, attributes of higher education institutions have a positive effect on information satisfaction at Universitas Khairun and are not significant for IAIN Ternate students. Third, the findings are quite surprising because information satisfaction positively affects selection satisfaction on Universitas Khairun and IAIN Ternate students. Fourth, it provides new findings that the information satisfaction variable is partial mediation and full mediation and independent variables.

\section{Acknowledgment}

The authors are grateful to express gratitude to those who have had the pleasure to cooperate during this research.

\section{Declaration of Conflicting Interests}

The authors have declared no potential conflicts of interest concerning the study, authorship, and/or publication of this article,

\section{References}

Ahmad, M. (2019). The Influence of Product Attribute and Reference Group Towards Customer Value of Moslem's Wear Kerawang Handycraft in Gorontalo Province. International Journal of Accounting $\mathcal{E}$ Finance in Asia Pasific (IJAFAP), 2(1), 1-12. Retrieved from http://www.ejournal.aibpm.org/index.php/IJAFAP/issue/view/22

Ardani, W., Rahyuda, K., Giantari, I. G. A. K., \& Sukaatmadja, I. P. G. (2019). Customer Satisfaction and Behavioral Intentions in Tourism: A Literature Review. International Journal of Applied Business and International Management, 4(3), 84-93. https:// doi.org/10.32535/ijabim.v4i3.686

Baron, R. M., \& Kenny, D. A. (1986). The moderator-mediator variable distinction in social psychological research: Conceptual, strategic, and statistical considerations. Journal of Personality and Social Psychology, 51(6), 1173-1182. https://doi.org/10.1037/00223514.51.6.1173

Brown, C., Varley, P., \& Pal, J. (2009). University course selection and services marketing. $\begin{array}{lllll}\text { Marketing Intelligence } \mathcal{E} \quad \text { Planning, } & \text { 310-325. }\end{array}$ https:/ / doi.org/10.1108/02634500910955227

Buamonabot, I., Nurlaila, N., \& Nurdin, N. (2019). Pengaruh Atribut Perguruan Tinggi Terhadap Kepuasan Memilih Perguruan Tinggi. Cakrawala Management Business Journal, 2(1), 281. https:/ / doi.org/10.30862/cm-bj.v2i1.19

Buamonabot, I., Syahdan, R., Arilaha, M. A., Fahri, J., \& . N. (2020). Atribut Perguruan Tinggi, Kepuasan Informasi, Kepuasan Pengguna Sistem Informasi dan Kepuasan Memilih Perguruan Tinggi (Studi pada Sistem Informasi Penerimaan Mahasiswa Baru). IJIS Indonesian Journal On Information System, 5(2). https://doi.org/10.36549/ijis.v5i2.88

Cha, S. S., \& Seo, B. K. (2019). Cafeteria Use by Students and Effect of Selection Attributes on Satisfaction. The Journal of Asian Finance, Economics and Business, 6(1), 187-194. https:// doi.org/10.13106/jafeb.2019.vol6.no1.187

Chapman, D. W. (1981). A Model of Student College Choice. The Journal of Higher Education, 52(5), 490. https:// doi.org/10.2307/1981837 


\section{Selection Satisfaction and Attributes of Higher Education Institutions: Mediation of Information Satisfaction}

Cubillo, J. M, Sánchez, J., \& Cerviño, J. (2006). International students' decision-making process. International Journal of Educational Management, 20(2), 101-115. https:/ / doi.org/10.1108/09513540610646091

Davignon, P. (2015). Factors Influencing College Choice and Satisfaction among Students at Christian Colleges and Universities. Religion $\mathcal{E}$ Education, 43(1), 77-94. https:/ / doi.org/10.1080/15507394.2015.1090811

Ghozali, I. (2018). Aplikasi analisis multivariete dengan program IBM SPSS 23. Semarang, Indonesia: Badan Penerbit Universitas Diponegoro.

Hair, J., Black, W., Babin, B., \& Anderson, R. (2010). Multivariate Data Analysis: A Global Perspective. In P. P. Hall (Ed.), Multivariate Data Analysis: A Global Perspective (7th ed., Vol. 7, p. ). Hallbergmoos, Germany: Pearson.

Halstead, D., Hartman, D., \& Schmidt, S. L. (1994). Multisource Effects on the Satisfaction Formation Process. Journal of the Academy of Marketing Science, 22(2), 114-129. https:// doi.org/10.1177/0092070394222002

Iglesias, M. P., \& Guillén, M. J. Y. (2002). Searching for information when selecting a restaurant. Food Service Technology, 2(1), 35-45. https:/ / doi.org/10.1046/j.1471-5740.2002.00032.x

Ismail, N. (2008). International Students' Satisfaction in Their Choice of A Private higher Education Institution. 9th International Business Research Conference, 24 November - 26 November. Melbourne, Australia.

Ismail, N., \& Leow, Y. M. (2008). Sourcing for information: A private higher education perspective. 9th International Business Research Conference. Melbourne, Australia.

Ismail, N. (2009). Mediating effect of information satisfaction on college choice. Oxford Business $\mathcal{E}$ Economics Conference Program, 1-23. St. Hugh's College, Oxford University, Oxford, UK.

Ismail, N., Faridah, H., Nooraini, M. S., \& Norzaidi, M. D. (2010). Determining Mediating Effect of Information Satisfaction on International Students' College Choice: Empirical Evidence in Malaysia's University. International Journal of Scientific Research in Education, 3(1), 51-63.

Ismail, N., Hassan, F. H., \& Sheriff, N. M. (2012, June). Student Satisfaction Formation: Linkage Between Information Satisfaction and College Choice Satisfaction. In European Conference on Research Methodology for Business and Management Studies (p. 181). Academic Conferences International Limited.

Ismail, N. (2013a). Characteristics influencing international students' information search and satisfaction on private higher education institution in Malaysia. In: The Doctoral Research Abstracts. IPSis Biannual Publication, 3(3). Retrieved from http://ir.uitm.edu.my/id/eprint/19069

Ismail, N. (2013b). Information Accessibility in the Selection of Information Sources in Higher Education: The Relevance of Marketer Controlled Sources. Journal of Global Management, 6(1), 11-21.

Jones, J. L., \& Shandiz, M. (2015). Service Quality Expectations: Exploring the Importance of SERVQUAL Dimensions from Different Nonprofit Constituent Groups. Journal of $\begin{array}{lllll}\text { Nonprofit } \mathcal{E} & \text { Public Sector } & \text { Marketing, } & 27(1), & 48-69 .\end{array}$ https:// doi.org/10.1080/10495142.2014.925762

Kotler, P., \& Armstrong, G. (2018). Principles of Marketing (15th Global ed.). Boston, USA: Pearson. 


\section{Selection Satisfaction and Attributes of Higher Education Institutions: Mediation of Information Satisfaction}

Lubbe, I., \& Petzer, D. (2016). Key information sources influencing prospective students university choice a South African perspective. South African Journal of Higher Education, 27(4). https:// doi.org/10.20853/27-4-275

Machmud, R. (2019). Study of Satisfaction of Information System Users in Study Program (SIMPRODI) in Gorontalo State University. International Journal of Applied Business $\mathcal{E}$ International Management, 4(1), 1-12. Retrieved from http://www.ejournal.aibpm.org/index.php/IJABIM/article/view/339/342

Maslowsky, C. (2014, December 17). Five Ways Higher Education Marketing Will Change in 10 Years. Retrieved from https://evolllution.com/opinions/ways-higher-educationmarketing-change-10-years/

Menon, M. E., Saiti, A., \& Socratous, M. (2006). Rationality, Information Search and Choice in Higher Education: Evidence from Greece. Higher Education, 54(5), 705-721. https:// doi.org/10.1007/s10734-006-9019-3

Murray, K. B. (1991). A Test of Services Marketing Theory: Consumer Information Acquisition Activities. Journal of Marketing, 55(1), 10. https:/ / doi.org/10.2307/1252200

Oliver, R. L. (1997). Satisfaction: A Behavioral Perspective on the Consumer. New York, USA: The McGraw Hill Companies, Inc.

Parasuraman, A., Zeithaml, V. A., \& Berry, L. L. (1985). A Conceptual Model of Service Quality and Its Implications for Future Research. Journal of Marketing, 49(4), 41-50. https:/ / doi.org/10.2307/1251430

Poock, M. C., \& Love, P. G. (2001). Factors Influencing the Program Choice of Doctoral Students in Higher Education Administration. NASPA Journal, 38(2), 203-223. https:/ / doi.org/10.2202/1949-6605.1136

Roscoe, A. M., Lang, D., \& Sheth, J. N. (1975). Follow-up Methods, Questionnaire Length, and Market Differences in Mail Surveys. Journal of Marketing, 39(2), 20-27. https:/ / doi.org/10.1177/002224297503900205

Sudarwo, R, Anfas, A., \& Buamonabot, I. (2018). Pengaruh Kepuasan Informasi terhadap Kepuasan Memilih Perguruan Tinggi. Bongaya Journal for Research in Management, 1(2), 18-24. Retrieved from https://ojs.stiembongaya.ac.id/index.php/BJRM/article/view/75

Sudarwo, R., Anfas, A., \& Buamonabot, I. (2019). Antecedents of Satisfaction Choosing Higher Education: An Empirical Evidence at the Universitas Terbuka. International Journal of Scientific and Technology Research, 8(10), 1601-1604. Retrieved from http:/ / www.ijstr.org/ paper-references.php?ref=IJSTR-1019-22957

Tjiptono, F. (2015). Strategi Pemasaran (4th ed.). Yogyakarta: Penerbit Andi.

Verghese, A., \& Kamalanabhan, T. J. (2015). Attributes influencing information search for College choice: An exploratory study. International Journal of Business Innovation and Research (IJBIR), 9(1), 34-51. Retrieved from http:/ / www.inderscience.com/offer.php?id=65952

Zhang, Q., Cao, M., Zhang, F., Liu, J., \& Li, X. (2019). Effects of corporate social responsibility on customer satisfaction and organizational attractiveness: A signaling perspective. Business Ethics: A European Review, 29(1), 20-34. https:/ / doi.org/10.1111/beer.12243 


\section{About the Authors}

1. Irfandi Buamonabot obtained his Bachelor of Economics from Universitas Khairun, Indonesia, in 2009 and his Master's degree in Human Resources Management from Universitas Gadjah Mada, Indonesia, in 2012. The author is an Assistant Professor at the Department of Management, Faculty of Economics and Business, Universitas Khairun, Indonesia.

E-Mail: irfandibbot@gmail.com

2. Muhammad Asril Arilaha obtained his Bachelor of Economics from Universitas Khairun, Indonesia, in 1999 and Master's degree in Strategic Management from Universitas Brawijaya, Indonesia, in 2006. The author is an Associate Professor at the Department of Management, Faculty of Economics and Business, Universitas Khairun, Indonesia.

E-Mail: asril_arilaha@unkhair.ac.id

3. Johan Fahri obtained his Bachelor of Economics from Universitas Khairun, Indonesia, in 2002, Master's degree in Project Management from University of Technology Sydney, Australia, in 2008, and Doctor of Philosophy in Project Management from University of Sidney, Australia, in 2019. The author is an Associate Professor at the Department of Management, Faculty of Economics and Business, Universitas Khairun, Indonesia.

E-Mail: johan.fahri@unkhair.ac.id 